Research, Society and Development, v. 11, n. 2, e49711225805, 2022

(CC BY 4.0) | ISSN 2525-3409 | DOI: http://dx.doi.org/10.33448/rsd-v11i2.25805

\title{
Epidemiological profile of pertussis in Brazil from 2010 to 2019: a systematic review
}

Perfil epidemiológico da coqueluche no Brasil entre os anos de 2010 a 2019: uma revisão

sistemática

Perfil epidemiológico de la coqueluche en Brasil de 2010 a 2019: una revisión sistemática

Received: 01/16/2022 | Reviewed: 01/20/2022 | Accept: 02/01/2022 | Published: 02/06/2022

Laura Marcela Teotônio Magalhães

ORCID: https://orcid.org/0000-0002-0820-971X Escola Superior da Amazônia, Brazil

E-mail: lauramagalhaes9875@gmail.com

Ana Kelly Carvalho Gomes

ORCID: https://orcid.org/0000-0002-0291-2201

Laboratório Beneficente de Belém, Brazil

E-mail: annagomes792@gmail.com

Vinicius Pacheco da Silva

ORCID: https://orcid.org/0000-0001-8117-320X

Instituto Evandro Chagas, Brazil

E-mail: viniciuspchc@icloud.com

Samir Mansour Moraes Casseb

ORCID: https://orcid.org/0000-0002-7419-3381

Instituto Evandro Chagas, Brazil

E-mail: samir.casseb@gmail.com

Marinês da Costa Farias

ORCID: https://orcid.org/0000-0003-3191-7156

Escola Superior da Amazônia, Brazil

E-mail: marinesfarias85.mf@gmail.com

Elizandra Carneiro Baía

ORCID: https://orcid.org/0000-0003-4137-7771

Instituto Evandro Chagas, Brazil

E-mail: elizandra.baia@hotmail.com

Marli de Oliveira Almeida

ORCID: https://orcid.org//0000-0001-7892-5634

Secretaria Municipal de Saúde, Brazil

E-mail: almeidamarli942@gmail.com

Diogo de Matos Botelho

ORCID: https://orcid.org/0000-0002-9387-9725

Escola Superior da Amazônia, Brazil

E-mail: deogo31@gmail.com

Milena Machado de Matos

ORCID: https://orcid.org/0000-0003-3276-4139

Escola Superior da Amazônia, Brazil

E-mail: milena.matos.med@gmail.com

\begin{abstract}
Pertussis is a respiratory infection that severely affects humans, caused by bacteria of the genus Bordetella, especially the species $B$. pertussis and B. parapertussis, presenting an important cause of infant morbidity and mortality. This disease has received little attention from government authorities over the years, which can cause the disease to reemerge in the future. This study aimed to carry out a systematic literature review on the epidemiology of pertussis in Brazil between the years 2010 to 2019. The study was carried out based on information collected in national (BVS, ANVISA, DATASUS) and international databases (PubMed, SciELO, CDC). When performing the statistical analysis of confirmed cases by region, there was a significant change in 2014 compared to other years in the Northeast region. While in the Southeast region, in 2013 there was a significant increase compared to 2012 and only reduced in 2015. In the South region, the increase in the number of cases occured sharply in 2012 and only decreased in 2017. In the CenterWest region, 2014 was the only year that showes considerable statistical variety. Regarding the age group, children under 1 year old and between 10 and 14 years old are the ones with the highest number of pertussis cases. Regarding gender, no significant changes were detected. Health surveillance, compulsory notification of cases added to social participation are essential, so this disease can be eradicated from Brazil and the world.
\end{abstract}

Keywords: Epidemiology; Pertussis; Public health surveillance. 
Research, Society and Development, v. 11, n. 2, e49711225805, 2022

(CC BY 4.0) | ISSN 2525-3409 | DOI: http://dx.doi.org/10.33448/rsd-v11i2.25805

\begin{abstract}
Resumo
A coqueluche é uma infecção respiratória que acomete severamente o ser humano, principalmente lactentes, sendo causada por bactérias do gênero Bordetella, principalmente as espécies $B$. pertussis e $B$. parapertussis, sendo uma importante causa de morbimortalidade infantil. Esta doença tem recebido pouca atenção das autoridades governamentais e da sociedade, o que pode fazer com que a doença re-emerja no futuro. Por isso, este estudo teve como objetivo realizar uma revisão sistemática sobre a epidemiologia da coqueluche no Brasil entre os anos de 2010 a 2019. Este, foi realizado com base em informações coletadas em bases de dados nacionais (BVS, ANVISA, DATASUS) e internacionais (PubMed, SciELO, CDC). Ao realizar a análise estatística dos casos confirmados por região, houve uma mudança significativa em 2014 em relação aos demais anos, na região Nordeste. Já na região Sudeste, em 2013 houve um aumento em relação a 2012 e só houve diminuição em 2015. Na região Sul, a elevação do número de casos ocorreu de forma acentuada em 2012 e só teve decréscimo em 2017. Por fim, o Centro Oeste, 2014 foi o único ano que mostrou uma variedade estatística considerável. Quanto à faixa etária, crianças de 1 ano e entre 10 e 14 anos são as que apresentaram maior número de casos de coqueluche. Em relação ao gênero, não foram detectadas mudanças significativas. Sendo assim, a vigilância em saúde associada a notificação compulsória dos casos e a participação social se configuram como pilares essenciais para que a coqueluche seja erradicada do Brasil e do mundo.
\end{abstract}

Palavras-chave: Epidemiologia; Coqueluche; Vigilância em saúde pública.

\title{
Resumen
}

La coqueluche es una infección respiratoria que afecta gravemente a los seres humanos, especialmente a los bebés, siendo causada por bacterias del género Bordetella, especialmente las especies B. pertussis y B. parapertussis, siendo una importante causa de morbilidad y mortalidad infantil. Esta enfermedad ha recibido poca atención por parte de las autoridades gubernamentales y la sociedad, lo que puede hacer que la enfermedad vuelva a aparecer en el futuro. Por lo tanto, este estudio tuvo como objetivo realizar una revisión sistemática de la epidemiología de la tos ferina en Brasil entre los años 2010 a 2019. Esta se llevó a cabo con base en información recolectada en bases de datos nacionales (BVS, ANVISA, DATASUS) e internacionales (PubMed, SciELO, CDC). Al realizar el análisis estadístico de los casos confirmados por región, hubo un cambio significativo en 2014 en comparación con otros años en la región Nordeste. En la región Sudeste, en 2013 hubo un aumento en comparación con 2012 y solo disminuyó en 2015. En la región Sur, el aumento en el número de casos ocurrió de manera pronunciada en 2012 y solo disminuyó en 2017. Finalmente, en el Medio Oeste, 2014 fue el único año que mostró una considerable variedad estadística. En cuanto al grupo de edad, los niños de 1 año y entre 10 y 14 años son los que presentan mayor número de casos de tos ferina. En cuanto al género, no se detectaron cambios significativos. Así, la vigilancia de la salud asociada a la notificación obligatoria de casos y la participación social son pilares fundamentales para la erradicación de la tos ferina en Brasil y en el mundo.

Palabras clave: Epidemiología; Coqueluche; Vigilancia en salud pública.

\section{Introduction}

Pertussis is an acute respiratory infection of worldwide distribution, characterized by whooping cough that compromises the human upper respiratory tract, such as the trachea and bronchi. It is considered a public health problem because of its high mortality in children, which over time has affected adolescents and adults, due to changes in the behavioral pattern of individuals through immunization (BRASIL, 2019; Polakok, 2017).

It is caused by bacteria of the genus Bordetella, especially the species Bordetella pertussis and Bordetella parapertussis, the main cause of diseases in humans (Koneman, 2018). Transmission occurs through direct contact with infected individuals who eliminate via aerosols (sneezing, coughing and speaking), respiratory droplets containing the microorganism, which has a high virulence power (Castro et al., 2017; Araújo, 2019; Tortora, 2012).

Diagnosis can be performed through microbiological culture of samples collected from the nasopharyngeal region for species isolation. Currently, other tests are also carried out, such as molecular assays, direct immunofluorescence and serology, which aim to detect the bacterial genotype and thus confirm the analysis (Brasil, 2014; Castro \& Milagres, 2017; Torres et al, 2015).

Later, with the introduction of the triple and tetravalent vaccines in Brazil in the 1990s, the country started to identify significant changes in the course of the disease, causing a reduction in the incidence of pertussis cases of 10.6 per 100,000 inhabitants in 2010 (vaccine coverage above 95\%) (Brasil, 2019). 
However, in 2011, the Disease Notification System (SINAN) reported a sporadic and inexplicable increase in the number of pertussis cases. This situation lasted until 2014, in some Brazilian regions, such as the Southeast, Northeast and South. These regions were the most affected, raising questions about whether it is eradicated or re-emerging in the country (Medeiros et al, 2017; Brasil, 2019)

Since pertussis can cause severe signs and symptoms in children, which can lead to death and even cause significant cases in adults, this study aims to systematically gather epidemiological data in order to assess the current panorama of the infection in Brazil.

\section{Methodology}

\subsection{Methodology type}

This work is a systematic, quantitative and descriptive review, which aims to investigate the incidence of pertussis in Brazil, during the years 2010-2019.

\subsection{Database}

The keywords "Pertussis in Brazil" and "Coqueluche no Brasil" were used to search for relevant articles, manuals and epidemiological bulletins on the subject, with an emphasis on the 5 regions (north, northeast, south, southeast and midwest) of the country. The main databases used were: SUS Portal (DATASUS), Virtual Health Library (BVS), US National Library Of Medicine (Pubmed), Scientific Electronic Library Online (ScieLO), Google Scholar, Ministry of Health (MS), National Health Surveillance Agency (ANVISA) and Centers for Disease Control and Prevention (CDC).

\subsection{Inclusion criteria}

As inclusion criteria, existing and published literature about pertussis in the period from 2010 to 2019 were used. 29 studies written in Spanish, English and Portuguese were included. Publications with epidemiological data from the 5 Brazilian regions, containing a diversity of information, such as: age, gender, diagnostic confirmation and case evolution were used as relevant methods.

\subsection{Exclusion criteria}

Any material with publication date prior to the year of 2010 were excluded, as well as articles that do not meet nor provide information relevant to the purpose of the research.

Initially, 100 articles were selected, and among these, 56 met the inclusion criteria, and the remaining 44 entered the exclusion criteria. The analysis was redone, so the most relevant works could be filtered, with analytical objectivity, and finally, 11 articles were selected.

\subsection{Statistical analysis}

The obtained data were registered in Microsoft Excel 365 software, and for analysis of the results, T-student and ANOVA tests were performed, that later were analyzed by Prism Graph 7.0 software (Prism, INC), considering the value of $\mathrm{p}<0.05$.

\section{Results and Discussion}

It was observed that during the years 2010 to 2019 shown in Figure 1, according to the region of residence, the 
following cases were notified:

In Southeastern Brazil, a total of 13,888 cases. The numbers of the disease remained fluctuating, but with a considerable increase in 2011 (1,249 cases), 2012 (2,700), 2013 (3,314), 2014 (2,890) and $2015(1,057)$.

In the Northeast region, 8,124 cases. Since the highest number occurred during the years $2013(1,009)$ and 2014 $(2,883)$

In the southern part of the country, 6,669 cases were confirmed, and this is similar to the Southeast region in relation to the fluctuation of annual notifications. Therefore, 1,461 cases emerged in 2012; 1,253 in 2013 and 1,465 in 2014.

In the Midwest, the comprehensive total was 2,327 confirmed notifications. And the years of the respective peaks of pertussis were 2013 (450 cases) and 2014 (789). Finally, in the North region, there were respectively a total of 1,841 cases, where the increase in notifications occurred in 2012 (310 cases), 2013 (354) and 2014 (471).

Figure 1. Cases confirmed by region of residence from 2010 to 2019.

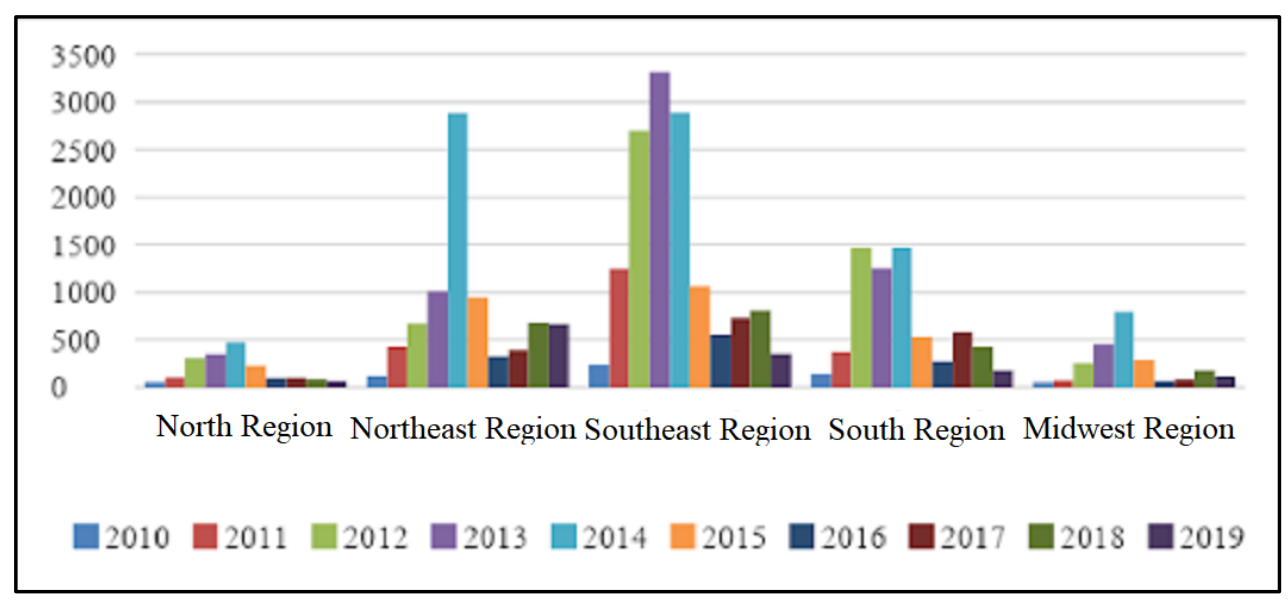

Source: DATASUS (2020).

With the statistical analysis of confirmed cases by region, it was observed that in the Southeast region, in 2013 there was a significant increase compared to $2012(\mathrm{p}=0.021)$ and only decreased in $2015(\mathrm{p}=0.038)$. There was a significant change in 2014 ( $\mathrm{p}=0.03$ ) compared to previous years in the Northeast region. When analyzing the South region, there was a sharp increase in cases in 2012 ( $\mathrm{p}=0.021$ ) and only decreased in 2017 ( $\mathrm{p}=0.032$ ). In the Midwest region, 2014 is the only year that demonstrated statistical change $(\mathrm{p}=0.0134)$.

Pertussis is a respiratory and infectious disease that affects mostly infants and children, as shown in Figure 2. Therefore, through Portal do SUS notifications (DATASUS), the age group affected by the disease, during the study period (2010-2019) was organized as it follows: 
Research, Society and Development, v. 11, n. 2, e49711225805, 2022

(CC BY 4.0) | ISSN 2525-3409 | DOI: http://dx.doi.org/10.33448/rsd-v11i2.25805

Figure 2. Cases confirmed by age group, from 2010 to 2019.

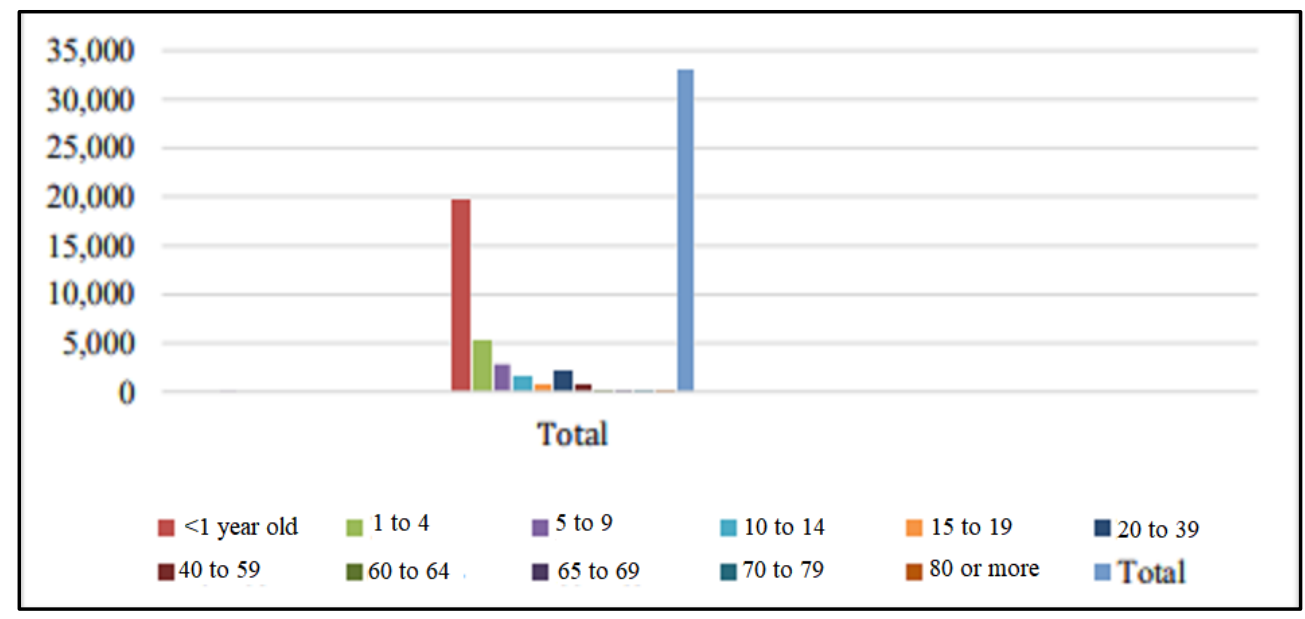

Source: DATASUS (2020).

Children under 1 year: a total of 19,793 cases were confirmed in the 5 regions of the country. From 1 to 4 years: a total of 5,207 cases were reported. In the age group from 5 to 9 years old, the cases reached 2,789. Between 10 and 14 years, the estimate was 1,573 cases. Ages 15 to 19 years old (529), 20-39 (2,035), 40-59 (776), 60-64 (64), 65-69 (46), 70-79 (28) and finally 80 or more: 15 confirmed cases.

When relating the number of cases with age groups, the ones with a considerable difference are the age groups under 1 year old $(\mathrm{p}=0.0245)$ and from 10 to 14 years old $(\mathrm{p}=0.0276)$. Therefore, only these two groups have a number of relevant pertussis cases.

Pertussis has a worldwide distribution and can affect male and female persons, as shown in Figures 3 and 4

Figure 3. Pertussis cases per region, between males (2010-2019).

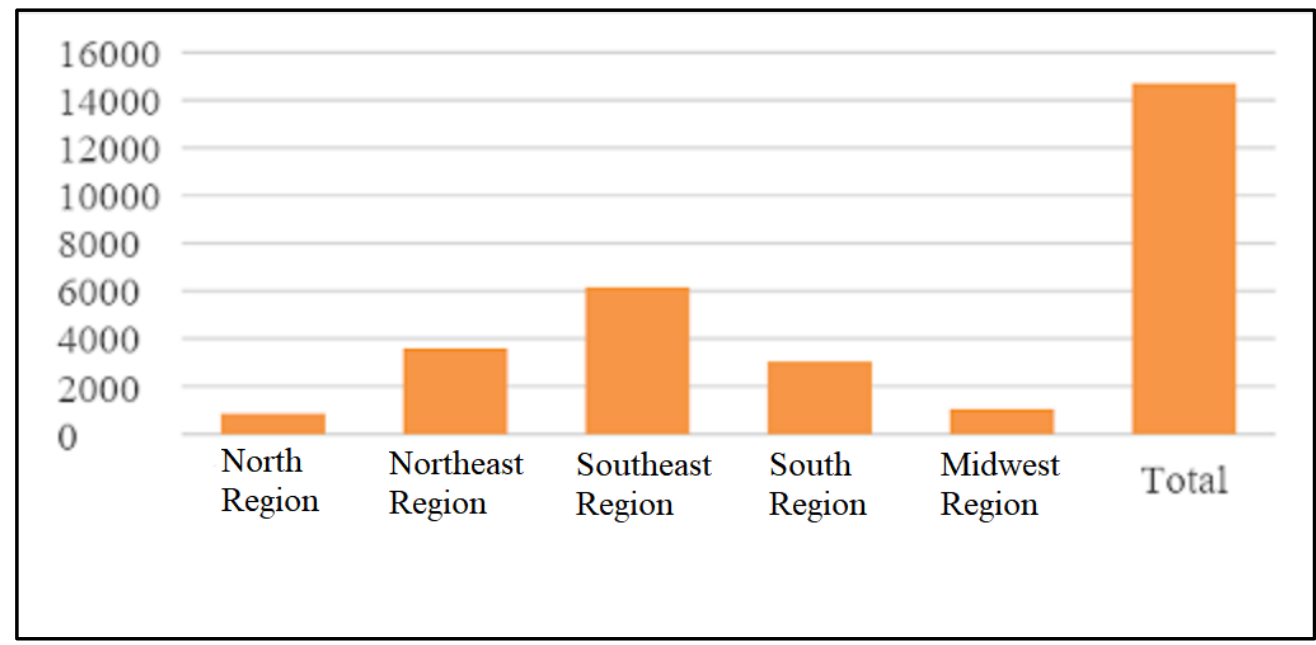

Source: DATASUS (2020). 
Research, Society and Development, v. 11, n. 2, e49711225805, 2022

(CC BY 4.0) | ISSN 2525-3409 | DOI: http://dx.doi.org/10.33448/rsd-v11i2.25805

Figure 4. Pertussis cases per region, between females (2010-2019).

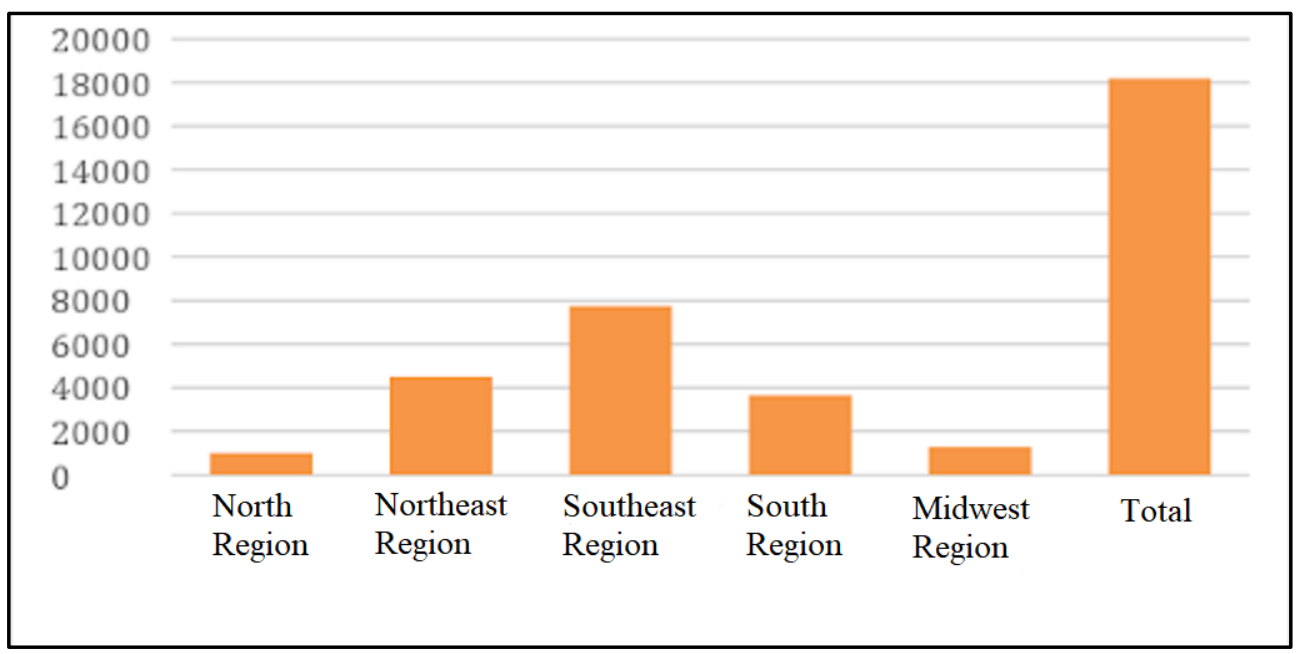

Source: DATASUS (2020).

In addition, according to notifications from the Brazilian Ministry of Health, a total of 32,882 cases of pertussis were reported in male and female populations. In the statistical analyses, we were able to assess that regarding gender, there was no significant change.

Pertussis, in the past, had already affected many infants and was an important cause of childhood morbidity and mortality. However, through the advent of vaccination, as well as antibiotic therapy, which is an excellent therapeutic method with new changes in its pathway, it is visible that the number of cured patients is significant when compared to deaths, as demonstrated in Figure 5 .

Figure 5. Cases confirmed by disease progression, by region (2010-2019).

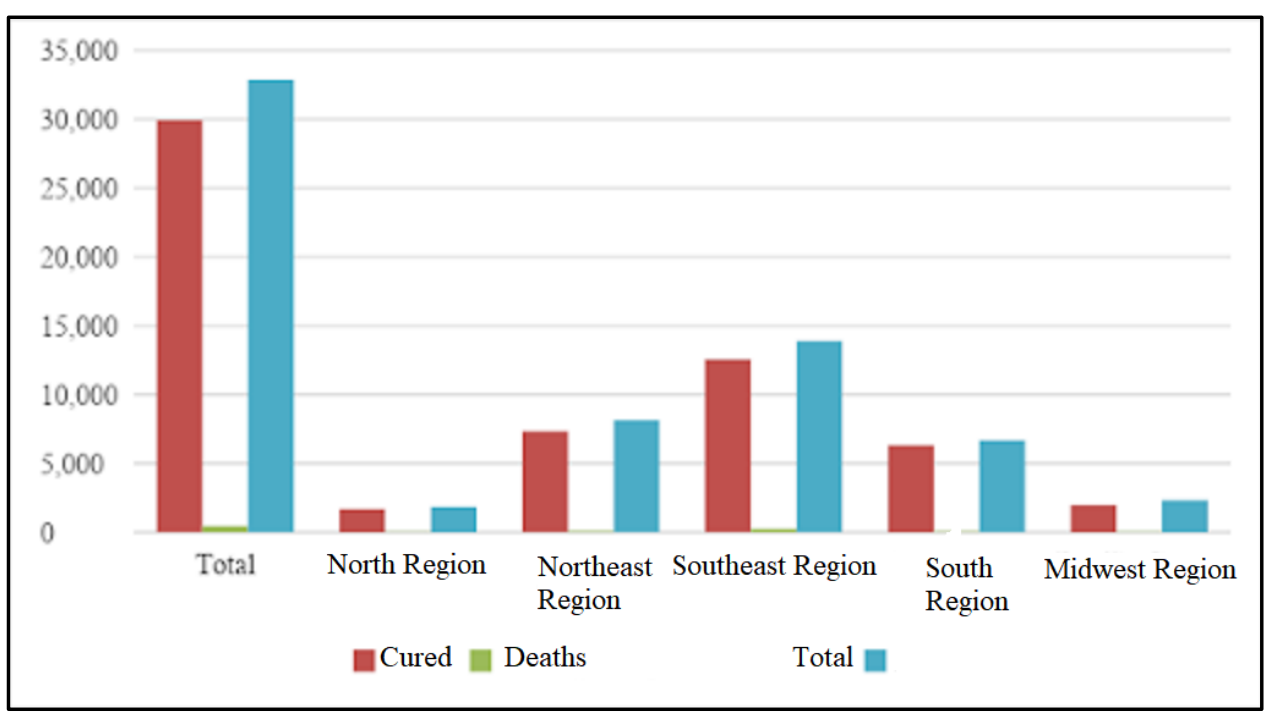

Source: DATASUS (2020).

The number of cured patients was 29,922 , representing $90.95 \%$ of the total amount. There were 467 deaths. The criteria for confirming the disease helps in its early detection, so that therapeutic prophylaxis reduces the pathology’s incidence, leading 
the cases to significantly progress to cure, as shown in Figure 5.

Figure 6. Confirmed cases by diagnostic type, from 2010 to 2019.

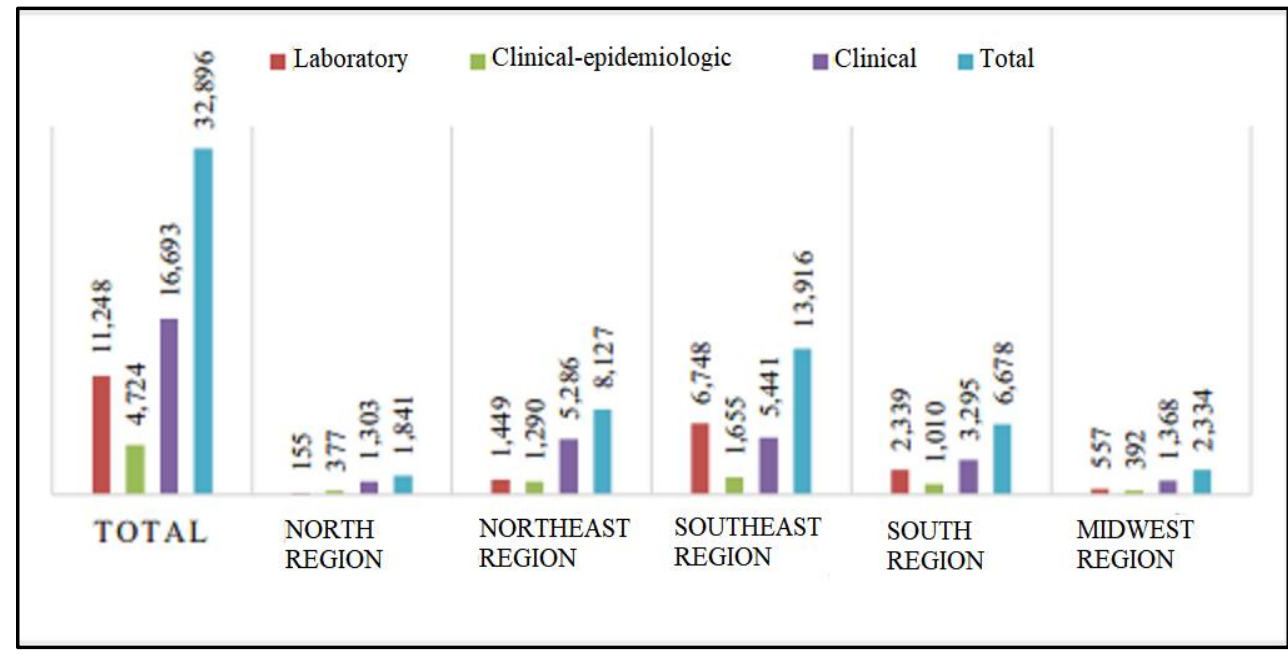

Source: DATASUS (2020).

Thus, the percentages by diagnostic type were: $51.10 \%$ (clinical), $34.44 \%$ (clinical-epidemiological) and $14.46 \%$ (laboratory).

Therefore, there was an exponential growth from 2011 to 2014, since, theoretically, all regions were affected. The Southeast was one of the most affected regions in this regard, due to the fact that this place is home to a large portion of the population, being the most populous region in the country, with more than 70 million inhabitants, as well as its seasonality characteristics.

In Southeastern Brazil, there is great social agglomeration, in addition to the predominance of a tropical weather, with well-defined seasons, where there is an increase in the circulation of Bordetella pertussis strains, especially between spring and summer, where temperatures vary around $30^{\circ} \mathrm{C}$, thus facilitating bacterial metabolism and the consequent transmission of the disease. In the South, this reality is very similar, with changes in the region's climate, facilitating disease transmission in a period similar to the previous region. In the Northeast region, the onset of the disease remained fluctuating and also on the rise from 2012, being similarly associated with the Southeast, due to a large population influx in the states that comprise it, due to the predominant tourism in beaches, restaurants and other facilities. Furthermore, the equatorial-tropical weather in the Northeast facilitates the spread of the disease, with its coastal and semi-arid incidence and high temperatures that can vary from $28^{\circ} \mathrm{C}$ to 32 ${ }^{\circ} \mathrm{C}$. In the North, the number of cases is less incident, being correlated with a wider territory and a good population distribution, in addition to temperature variations around $24{ }^{\circ} \mathrm{C}$ to $32{ }^{\circ} \mathrm{C}$, which reduces the occurrence of cases of the disease, since the pathogen needs a stable temperature to propagate. Finally, the Midwest region, similarly to the North region, has the social distribution expanded in its vast territory, also causing a reduction in the number of cases of Bordetella pertussis (Castro \& Milagres, 2017; Dias, 2017; Nogueira, 2015; Oliveira et al, 2018; Silva, 2017).

Therefore, the age group most affected by pertussis are still infants under 1 years old, corroborating the findings that explain that this is attributed to the lack of vaccination of infants, and/or inadequate vaccination, where they did not receive the three doses of the vaccine (Brasil, 2019; Aguiar et al, 2015; Gryninger, 2016). 
Research, Society and Development, v. 11, n. 2, e49711225805, 2022

(CC BY 4.0) | ISSN 2525-3409 | DOI: http://dx.doi.org/10.33448/rsd-v11i2.25805

Pertussis can reach different groups in society, however, the number of cases were more extensive in females, and studies suggest that the detection of cases incidentally happens due to more intense surveillance of pertussis in women, especially during the gestational period, through prenatal examinations. Furthermore, with the replacement of erythromycin by azithromycin, there was an improvement in the treatment of pertussis, which became a disease that in most cases evolves towards a cure, due to the existing vaccination and effective therapeutic protocols (Castro \& Milagres, 2017; Medeiros et al, 2017).

Therefore, the clinical diagnosis is essential, considering that the laboratory method for bacterial isolation may be more difficult, as even if the microbiological detection of B. pertussis and B. parapertussis is considered the gold standard, it may have a low sensitivity, with variance in the positivity if the collection of biological sample from nasopharyngeal aspirate is not performed in the first weeks of symptoms and prior to antibiotic therapy (Brasil, 2017; Machado, 2019).

The incidence of cases is still apparent in Brazil and signs of reemergence of pertussis can be observed through the increase in the number of sporadic cases that happen annually due to several reasons: problems in the epidemiological surveillance system facing the disease, loss of immunity of vaccinated persons over the years, lack of vaccine boosters, in addition to the lack of diagnostic methods, such as qPCR, which are more sensitive and guarantee reliability in the results (Telles, 2012; Torres, 2015).

Pertussis is still an assiduous disease in the Brazilian territory, constituting a considerable portion of cases during a sporadic period of 3 to 5 years. Therefore, social participation is highly important, so the disease can be prevented, in addition to greater attention from government authorities regarding vaccine distribution in places of difficult access and the intensification of vaccine campaigns that help the population in decision-making to protect from the disease (Korppi, 2013; Berezin, 2014)

\section{Conclusion}

Thus, it could be observed that the possible significant changes in pertussis prevalence occurred in some parameters analyzed statistically, such as region of residence and age group affected by the disease. Therefore, it is notorious that pertussis is still impactful in Brazil. For this reason, it is of great importance to continue health surveillance, compulsory notification of cases, added to the knowledge of health professionals in the execution and provision of reliable laboratory and clinical results, in addition to social participation in immunization campaigns, so that pertussis can be eradicated in the future.

As previously reported, whooping cough, despite being a notifiable disease, is still included in the group of neglected diseases in Brazil and worldwide. In this way, it is suggested that new epidemiological studies be carried out constantly, covering not only the child population, which in fact is the most affected, but also the adult age group, so that it is possible to verify if the disease is presenting a new pattern of involvement and to assist health professionals and government authorities, as well as the population, in raising awareness of the importance of vaccination and for early combating the disease, as well as subsequent health surveillance.

\section{References}

Brasil (2010). Módulos de Princípios de Epidemiologia Para o Controle de Enfermidades. Organização Pan-Americana da Saúde. Brasília 48 p. Brasil (2013). Azitromicina. Norma Técnica nº 243. Consultoria Jurídica /Advocacia Geral da União. Brasília. 3 p. Brasil (2015). Ampliação do uso da azitromicina $250 \mathrm{mg}$ para tratamento ou quimioprofilaxia da coqueluche. Conitec. Brasília. 18 p. Brasil (2017). Secretaria de vigilância em saúde. Coordenação-geral de desenvolvimento da epidemiologia em serviço. Guia de vigilância em saúde. Brasília. Brasil (2019). Guia de Vigilância em Saúde: volume único [recurso eletrônico] / Ministério da Saúde. Secretaria de vigilância em saúde. Coordenação geral de desenvolvimento de Epidemiologia em serviços. Brasília. 740 p. 
Research, Society and Development, v. 11, n. 2, e49711225805, 2022

(CC BY 4.0) | ISSN 2525-3409 | DOI: http://dx.doi.org/10.33448/rsd-v11i2.25805

Brasil (2019). Protocolo de Vigilância Epidemiológica da Coqueluche. Ministério da Saúde. Minas Gerais. 30 p.

Brasil (2019). Secretaria de Vigilância em Saúde. Vigilância em saúde no Brasil. 154 p.

Cdc Centers for Disease Control and Prevention (2020). Vigilância e relatórios 2019. https://www.cdc.gov/pertussis/surv-reporting.html.

Cdc Centers for Disease Control and Prevention. Vigilância e relatórios 2019. https://www.cdc.gov/vaccines/pubs/surv-manual/chpt-10-pertussis.html.

Araújo, T. M. S., de Araújo, T. M. S., \& Barbosa, K. L. (2019). Mecanismos efetores da resposta imune na infecção por Bordetella pertussis. Arquivos de Ciências da Saúde da UNIPAR, 23(2).

Castro, H. W. V. \& Milagres, B. S. (2017). Perfil epidemiológico dos casos de coqueluche no Brasil de 2010 a 2014. Universitas: Ciências da Saúde, 15(2), 81-90.

Oliveira, F. A. C., Pereira, F. D. A. R., Fachini, J. S., Junior, G. D., \& Ferlin, L. L. (2018). Perfil epidemiológico das internações suspeitas de coqueluche em hospital universitário pediátrico do sul do brasil. Arquivos Catarinenses de Medicina, 47(1), 95-105.

Dias, F. C., Liberato, A. A., Lobo, P. H. P., Gusmão, K. E., de Santana, V. M. X., de Souza, O. V., \& Guedes, V. R. (2017). Perfil epidemiológico da coqueluche na região norte do brasil entre 2012 E 2015. Revista de Patologia do Tocantins, 4(2), 72-76.

Gryninger, L. C. F. Estudo descritivo de série histórica da coqueluche no Brasil no período de 2006 a 2013. Universidade de São Paulo

Gushiken, C. Y., Saeki, E. K., Martins, L. M., Pereira, J. C., \& Leite, D. (2018). Identificação laboratorial da coqueluche na região do oeste do Estado de São Paulo. Revista do Instituto Adolfo Lutz, 77, 1-6.

Korppi, M. (2013). Coqueluche: ainda um desafio. Jornal de Pediatria, 89, 520-522.

Machado, M. B., \& Passos, S. D. (2019). Coqueluche grave na infância: atualização e controvérsias-revisão sistemática. Revista Paulista de Pediatria , 37 , 351-362.

Medeiros, A. T. N. D., Cavalcante, C. A. A., Souza, N. L. D., \& Ferreira, M. A. F. (2017). Reemergência da coqueluche: perfil epidemiológico dos casos confirmados. Cadernos Saúde Coletiva, 25, 453-459.

Nogueira, K. R. C. (2019). Perfil epidemiológico dos atendimentos dos casos suspeitos de coqueluche em um hospital particular de Maceió no período de 2013 a 2017. Revista de Epidemiologia e Controle de Infecção, 9(4), 287-291.

Polakok, N. M. Z. (2017). Desenvolvimento de um método diagnóstico diferencial para Bordetella pertussis usando reagentes produzidos no Brasil. Fundação Oswaldo Cruz. Curitiba 89 p.

Silva, L. M. N., Graciano, A. R., Montalvão, P. D. S. D., \& de Jesus França, C. M. (2017). O atual e preocupante perfil epidemiológico da coqueluche no Brasil-The current and worrisome epidemiology of pertussis in Brazil. Revista Educação em Saúde, 5(1), 21-27

Telles APA. Coqueluche. Hospital do Servidor Público Municipal. 56 p.

Tortora, G. J., Case, C. L., \& Funke, B. R. (2016). Microbiologia-12a Edição. Artmed Editora.

Torres, R. S., Santos, T. Z., Torres, R. A., Pereira, V. V., Fávero, L. A. M. Filho, O. R., \& Araujo, L. S. (2015). Ressurgimento da coqueluche na era vacinal: aspectos clínicos, epidemiológicos e moleculares. Jornal de Pediatria , 91 , 333-338.

Vaz, T. M., Leite, D, \& Kinue, I. (2010). Coqueluche: Manual de diagnóstico laboratorial do Instituto Adolfo Lutz. Instituto Adolfo Lutz, Centro de Bacteriologia, Laboratório de Referência Nacional para Coqueluche. 